\title{
Физиология
}

DOI: $10.14529 / \mathrm{hsm} 18 \mathrm{~s} 01$

\section{ELECTROCARDIOGRAPHIC VALUES ASSOCIATED WITH SERPAIN (PAI-1) GENE MUTATION SENSITIVITY IN YOUNG ATHLETES FOR FORECASTING CARDIOVASCULAR DISORDERS}

\author{
D.Z. Shibkova1, shibkova2006@mail.ru, ORCID:0000-0002-8583-6821, \\ V.B. Yarysheva ${ }^{2}$, yarysheva@list.ru, ORCID: 0000-0002-6713-6637, \\ P.A. Baiguzhin 1, baiguzhinpa@cspu.ru, ORCID: 0000-0002-5092-0943, \\ Yu.N.Romanov', kickbox@mail.ru, ORCID:0000-0002-0516-9505 \\ ${ }^{1}$ South Ural State University, Chelyabinsk, Russian Federation, \\ ${ }^{2}$ Clinic of Aesthetic Surgery Venous, Chelyabinsk, Russian Federation
}

\begin{abstract}
Aim. The article deals with establishing the peculiarities of ECG contour analysis in athletes with various SERPINE1 (PAI-1) genotypes depending on their gender. Materials and methods. We examined 200 athletes from national teams, including 107 boys aged $14.95 \pm 1.57$ and 93 girls aged $15.04 \pm 1.67$. ECG registration was performed in standard conditions using SENSITEG 1003 equipment. SERPINE1 PAI-1 gene mutation was assessed with the help of polymerase chain reaction using REALTIME DNA-technologies. We processed the results of the study using SPSS integrated statistical system. Results. We revealed that $44.1 \%$ and $55.1 \%$ of female and male athletes, respectively, possess SERPINE1 (PAI-1) gene heterozygous form. Dominant genotype was revealed in $23.7 \%$ and $33.6 \%$ of female and male athletes, respectively, while recessive genotype was found in $32.3 \%$ and $11.2 \%$ of female and male participants, respectively. Prolonged QRS, P intervals, associated with SERPINE1 (PAI-1) recessive genotype, are more typical for male participants (7-10\%). Decreased HR and alpha angle values in persons with recessive genotype are 1.7 and 2.7 times more common for female athletes. Conclusion. We revealed electrocardiographic indicators, associated with SERPINE1 (PAI-1) gene mutation in young athletes. These indicators are significant for the assessment of cardiovascular disease risks. It was established that persons with SERPINE1 (PAI-1) 4G/4G genotype can practice professional sports only under the supervision of a cardiologist.
\end{abstract}

Keywords: SERPINE1 PAI-1 gene polymorphism, ECG (electrocardiography), young athletes, cardiovascular disorders.

Introduction. One of the most important issues of sports medicine and physiology is the choice of selection criteria for the children, able to cope with intense psycho-emotional and physical loads and to demonstrate significant sports results without damage to health. However, there is a tendency for health deterioration not only in children and adolescents, but also in persons involved in sports $[2,5]$. The examination of young athletes revealed cardiac rhythm and conduction disorders [1, 2]. Some professional adolescent athletes demonstrated a significant increase in the total number of hypertensive, dystonic, and adverse reactions. This proves the presence of expressed functional disorders in regulatory systems and low adaptation capacities [3].

The prevalence/incidence of sudden death in young competitive athletes due to cardiovascular diseases has become an important part of the debate over the most effective and applicable preparticipation screening strategies for this population [10].

According to the data provided by M. Dennis et all (2018), from 15 young athletes' deaths, $5(33 \%)$ were of an arrhythmogenic or presumed arrhythmic character, and 5 (33\%) occurred due to inherited cardiomyopathies (2 hypertrophic cardiomyopathies, 3 arrhythmogenic right ventricular cardiomyopathies) [8].

In the prognosis of cardiovascular diseases, special importance is to be paid to the risk factors of an atherosclerosis [12] and venous thromboembolism associated with a birth defect - mutations in the genes encoding anticoagulants [9]. According to the results of the study [6] dedicated to the frequency of prothrombin mutation, Leiden 


\section{Физиология}

mutation, and T/T variation of rs 1801133 MTHFR gene in juniors and athletes, these parameters either did not differ, or were slightly higher than in the control group.

The comprehensive analysis of genetic polymorphisms in fibrinolysis and blood coagulation systems, as well as the analysis of the genes of folate cycle and platelet adhesion indicate a possible risk for athletes, which exists due to increased thrombosis. A possible negative effect may be a mutation of SERPINE PAI 1 gene, which can cause sudden death or acute myocardial infarction due to the risk of thromboembolism. This is demonstrated that the risk of venous thrombosis increases only in persons with protein $\mathrm{S}$ deficiency and homozygous for $4 \mathrm{G}$ allele. For the heterozygous type of this polymorphism $(4 \mathrm{G} / 5 \mathrm{G})$, the risk of cardiovascular disease slightly increases. the basis of informed consent with the help of 12-channel certified SENSITEG 1003 equipment after $5 \mathrm{~min}$ rest in a horizontal position.

To assess SERPINE1 (PAI-1) gene mutation, we took blood from the ulnar vein. Genotype determination was carried out with the help of polymerase chain reaction using REALTIME DNA-technologies. Statistical processing of the results was performed by means of SPSS v. 23.0 for Windows using Fisher's F-test to test the hypothesis about the equality of numerical characteristics in data distributions.

The analysis of ECG parameters when comparing the relative values of SERPINE1 (PAI-1) gene variants distribution revealed no differences depending on the athletes' gender.

Research results. Table 1 demonstrates ECG intervals, heart rate, and alpha angle values for young athletes.

Distribution of young athletes, depending on gender and the results of ECG contour analysis, \%

\begin{tabular}{|l|c|c|c|c|c|c|c|}
\hline \multicolumn{2}{|c|}{} & P, ms & PQ, ms & QRS, ms & QT, ms & $\begin{array}{c}\text { Beats } \\
\text { per minute }\end{array}$ & $\begin{array}{c}\text { Alpha angle, } \\
\text { degrees }\end{array}$ \\
\hline \multirow{2}{*}{$\begin{array}{l}\text { Girls } \\
(\mathrm{n}=93)\end{array}$} & $<\mathrm{N}$ & 4,3 & 21,3 & - & - & 52,1 & 63,8 \\
\cline { 2 - 8 } & $\mathrm{N}$ & 50,0 & 74,4 & 44,7 & 66,0 & 44,7 & 36,2 \\
\cline { 2 - 8 } \begin{tabular}{l}
\multirow{2}{*}{$\begin{array}{l}\text { Boys } \\
(\mathrm{n}=107)\end{array}$} \\
\cline { 2 - 8 }
\end{tabular} & $<\mathrm{N}$ & 45,7 & 4,3 & 55,3 & 34,0 & 3,2 & - \\
\cline { 2 - 8 } & $>\mathrm{N}$ & 45,0 & 9,2 & - & - & 42,7 & 46,4 \\
\hline
\end{tabular}

It was established that abnormal alleles of the polymorphisms studied occur with different frequency in different populations and are not always associated with the risk of cardiovascular diseases. Further genetics associated studies will help to identify genetic markers of cardiovascular diseases [4].

The importance of our study is connected with the analysis of electrocardiographic markers, associated with SERPIN (PAI-1) gene mutation, and their informative value in the prognosis of cardiovascular accidents in adolescents, involved in sports.

Aim. The article deals with establishing the sensitivity of electrocardiographic values, associated with SERPAIN (PAI-1) gene mutation, in young athletes and forecasting cardiovascular accidents.

Materials and methods. We examined 200 athletes from national teams, including 107 boys aged $14.95 \pm 1.57$ and 93 girls aged $15.04 \pm 1.67$. ECG registration was performed on
The expected results in both groups are the decrease of heart rate values and the increase of QRS interval, which is more pronounced in girls. $\mathrm{P}$ interval prolongation was found in almost a half of the subjects regardless of gender; QT interval prolongation was more typical in the group of girls $(13.1 \%)$. In girls, alpha angle decreased by $17.4 \%$ in comparison with boys.

We revealed rhythm and conduction disorders in the group of young athletes: bradycardia in $22(10.7 \%)$ persons, tachycardia in $14(6.8 \%)$ athletes, incomplete right and left bundle branch block in $16(7.7 \%)$, disturbance of the repolarization of the left ventricle in $5(2.4 \%)$ [7]. These features of ECG values are connected with adaptive processes in the regulatory mechanisms of subjects under increased physical loads.

In order to assess the effect of SERPINE (PAI-1) gene polymorphism on ECG intervals duration, heart rate, and alpha angle values, athletes of both groups were divided into 3 subgroups depending on genotypes (Table 2). 
Distribution of young athletes with SERPINE1 (PAI-1) genotype, depending

Table 2 on the results of ECG contour analysis, \%

\begin{tabular}{|c|c|c|c|c|c|c|c|}
\hline \multirow[b]{2}{*}{ Value } & \multirow[b]{2}{*}{ Variant } & \multicolumn{3}{|c|}{ Boys $(n=107)$} & \multicolumn{3}{|c|}{ Girls $(n=93)$} \\
\hline & & $\begin{array}{l}4 \mathrm{G} / 4 \mathrm{G} \\
\mathrm{n}=12\end{array}$ & $\begin{array}{l}5 \mathrm{G} / 4 \mathrm{G} \\
\mathrm{n}=59\end{array}$ & $\begin{array}{l}5 \mathrm{G} / 5 \mathrm{G} \\
\mathrm{n}=36\end{array}$ & $\begin{array}{l}4 \mathrm{G} / 4 \mathrm{G} \\
\mathrm{n}=30\end{array}$ & $\begin{array}{l}5 \mathrm{G} / 4 \mathrm{G} \\
\mathrm{n}=41\end{array}$ & $\begin{array}{l}5 \mathrm{G} / 5 \mathrm{C} \\
\mathrm{n}=22\end{array}$ \\
\hline \multirow{3}{*}{$\mathrm{P}$} & $<$ & 8,3 & 1,7 & - & 6,7 & 4,9 & - \\
\hline & $\mathrm{N}$ & 41,7 & 33,9 & 61,1 & 53,3 & 43,9 & 54,5 \\
\hline & $>$ & 50,0 & 64,4 & 38,9 & 40,0 & 51,2 & 45,5 \\
\hline \multirow{3}{*}{ PQ } & $<$ & 8,3 & 10,2 & 5,6 & 23,3 & 24,4 & 13,6 \\
\hline & $\mathrm{N}$ & 83,3 & 91,5 & 97,2 & 80,0 & 70,7 & 77,3 \\
\hline & $>$ & 8,3 & - & 2,8 & - & 4,9 & 9,1 \\
\hline \multirow{2}{*}{ QRS } & $\mathrm{N}$ & 50,0 & 32,2 & 36,1 & 60,0 & 34,1 & 40,9 \\
\hline & $>$ & 50,0 & 69,5 & 69,4 & 43,3 & 65,9 & 59,1 \\
\hline \multirow{2}{*}{ QT } & $\mathrm{N}$ & 75,0 & 83,1 & 80,6 & 60,0 & 65,9 & 68,2 \\
\hline & $>$ & 25,0 & 18,6 & 25,0 & 43,3 & 34,1 & 27,3 \\
\hline \multirow{3}{*}{ Heart rate } & $<$ & 33,3 & 49,2 & 47,2 & 56,7 & 58,5 & 54,5 \\
\hline & $\mathrm{N}$ & 50,0 & 49,2 & 58,3 & 43,3 & 39,0 & 31,8 \\
\hline & $>$ & 8,3 & 1,7 & - & - & 2,4 & 9,1 \\
\hline \multirow{2}{*}{ Alpha angle } & $<$ & 25,0 & 57,6 & 63,9 & 66,7 & 56,1 & 72,7 \\
\hline & $\mathrm{N}$ & 75,0 & 44,1 & 41,7 & 33,3 & 43,9 & 27,3 \\
\hline
\end{tabular}

We revealed that $44.1 \%$ and $55.1 \%$ of female and male athletes, respectively, possess SERPINE1 (PAI-1) gene heterozygous form. Dominant genotype was revealed in $23.7 \%$ and $33.6 \%$ of female and male athletes, respectively, while recessive genotype was found in $32.3 \%$ and $11.2 \%$ of female and male participants, respectively.

In the prognosis of cardiovascular accidents, persons with SERPINE (PAI-1) gene recessive genotype are at risk. So, we analyzed the group of athletes - carriers of this genotype.

Table 2 demonstrates that prolonged QRS, $\mathrm{P}$ intervals, associated with SERPINE1 (PAI-1) recessive genotype, are more typical for male participants (7-10\%); in girls, prolonged QT interval can be registered 1.7 times more often than in boys. The number of female athletes with a short PQ interval almost three times exceeds the number of male athletes. Decreased HR and alpha angle values in persons with recessive genotype are 1.7 and 2.7 times more common for female athletes.

Conclusion. Screening remains contentious due to the challenges of identifying relatively rare entities amongst a healthy cohort. The imperfect diagnostic accuracy of all existing tests means that screening strategies have potential for harm through incorrect diagnoses as well as the potential for identification of important subclinical pathologies. The management of athletes at risk of ventricular arrhythmias and sudden cardiac death is similarly complex [11].
During the assessment of ECG intervals in both groups, we registered the predominance of persons with prolonged P intervals, QRS, QT, and reduced values of heart rate and angle alpha.

It was established that persons with SERPINE1 (PAI-1) 4G/4G genotype can practice professional sports only under the supervision of a cardiologist. If there are any injuries, the risks associated with thrombosis must be taken into account.

\section{References}

1. Degtyaryova E.A., Kantemirova M.G., Zhdanova O.I., Trosheva O.N. [Myocarditis in Young Athletes]. Kazanskij meditsinskij zhurnal [Kazan Medical Journal], 2015, no. 96 (4), pp. 669-674. (in Russ.)

2. Komolyatova V.N., Makarov L.M., Fedina N.N., Kiseleva I.I., Bessportochnyj D.A. [Ventricular Arrhythmias in Young Elite Athletes]. Pediatriya. Zhurnal im. G.N. Speranskogo [Pediatrics. Journal Them. G.N. Speransky], 2015, no. 94 (2), pp. 105-109. (in Russ.)

3. Kurnikova M.V. [Physical Development and Morbidity of Highly Skilled Athletes of Adolescence]. Uchenye zapiski SPb GMU im. I.P. Pavlova [Scientific Notes SPbGMU Them. I.P. Pavlova], 2008, no. 15 (4), pp. 65-66. (in Russ.)

4. Levickij S.N., Pervuhina O.A., Bebyakova N.A. [Role of Polymorphism of Genes of the Renin-Angiotensin System in the Formation of Cardiovascular Pathology]. Vestnik Severnogo 


\title{
Физиология
}

(Arkticheskogo) federal'nogo universiteta. Ser. Mediko-biologicheskie nauki [Bulletin of the Northern (Arctic) Federal University. Ser. Biomedical Sciences], 2016, no. 4, pp. 30-39. (in Russ.) DOI: 10.17238/issn2308-3174.2016.4.30

5. Makarova G.A., Gurevich T.S., Achkasov E.E., Yur'ev S.Yu. Elektrokardiogramma sportsmena: norma, patologiya $i$ potentsial'no opasnaya zona [Electrocardiogram of the Athlete. Norm, Pathology and Potentially Dangerous Zone]. Moscow, SPORT Publ., 2018. 256 p.

6. Pushkarev V.P., Dyatlov D.A., Lekoncev E.V., Rahmanina L.V., Pushkarev E.D., Vishnev V.Yu., Kulikov L.M. [Study of the Influence of Genetic Variations Associated with Thrombophilia on Athletic Success]. Lechebnaya fizkul'tura i sportivnaya meditsina [Therapeutic Exercise and Sports Medicine], 2011, no. 12, pp. 23-28. (in Russ.)

7. Yarysheva V.B., Shibkova D.Z. [Genetic Predictors of Adapting the Cardiovascular System of Adolescents to Physical Activity]. Kazanskij medicinskij zhurnal [Kazan Medical Journal], 2011, no. 12, pp. 23-28. (in Russ.) DOI: $10.17750 / \mathrm{KMJ} 2017-63$

8. Dennis M., Elder A., Semsarian C., Orchard J., Puranik R. A 10-Year Review of Sudden
Death During Sporting Activities. Heart Rhythm, 2018, vol. 15 , iss. 10 , pp. $1477-1483$. DOI: 10.1016/j.hrthm.2018.04.019

9. Bollen L., Peetermans M., Peeters M., Steen K.V., Gils A. Active PAI-1 as Marker for Venous Thromboembolism: Case-Control Study Using a Comprehensive Panel of PAI-1 and TAFI Assays. Thrombosis Research, 2014, no. 134 (5), pp. 1097-1102.

10. Maron B.J., Murphy C.J., Haas T.S., Ahluwalia A., Garberich R.F. Strategies for Assessing the Prevalence of Cardiovascular Sudden Deaths in Young Competitive Athletes. International Journal of Cardiology, 2014, vol. 173, iss. 3, pp. 369-372. DOI: 10.1016/j.ijcard.2014.02.021

11. Flannery M.D., Gerche A.L. Sudden Death and Ventricular Arrhythmias in Athletes: Screening, De-Training and the Role of Catheter Ablation. Heart, Lung and Circulation, In press, uncorrected proof, Available online 19 Oct. 2018. DOI: 10.1016/j.hlc.2018.10.004

12. Liu Y., Cheng J., Guo X., Mo J., Li Z. The Roles of PAI-1 Gene Polymorphisms in Atherosclerotic Diseases: A Systematic Review and Meta-Analysis Involving 149,908 Subjects. Gene, 2018, no. 673, pp. 167-173. DOI: $10.1016 /$ j.gene. 2018.06 .040

Received 12 December 2018

Удк 616.1

DOI: $10.14529 / \mathrm{hsm} 18 \mathrm{~s} 01$

\section{ЭЛЕКТРОКАРДИОГРАФИЧЕСКИЕ ЗНАЧЕНИЯ, СВЯЗАННЫЕ С ЧУВСТВИТЕЛЬНОСТЬЮ ГЕННОЙ МУТАЦИИ SERPAIN (PAI-1) У МОЛОДЫХ СПОРТСМЕНОВ В ПРОГНОЗЕ СЕРДЕЧНО-СОСУДИСТЫХ НАРУШЕНИЙ}

\author{
Д.3. Шибкова ${ }^{1}$, В.Б. Ярышева", П.А. Байгужин1, Ю.Н. Романов ${ }^{1}$ \\ ${ }^{1}$ Южно-Уральский государственный университет, г. Челябинск, Россия, \\ ${ }^{2}$ ООО «Клиника «Венозная эстетическая хирургия», г. Челябинск, Россия
}

Цель: выявить особенности контурного анализа ЭКГ спортсменов с различным генотипом SERPINE1 (PAI-1) в зависимости от их половой принадлежности. Организация и методы. Было обследовано 200 спортсменов - членов сборных команд. В группе мальчиков $(\mathrm{n}=107)$ средний возраст составил $14,95 \pm 1,57$ года, в группе девочек $(\mathrm{n}=93)-$ $15,04 \pm 1,67$ года. Регистрация ЭКГ проводилась в стандартных условиях на аппарате SENSITEG 1003. Оценка мутации гена SERPAIN PAI-1 проводилась методом полимеразной цепной реакции на приборе REALTIME ДНК-технологии. Обработка результатов исследования была проведена средствами интегрированной статистической системы SPSS. 
Результаты. Установлено, что доля носителей гетерозиготной формы гена SERPINE1 (PAI-1) составила 44,1 и 55,1 \% у девушек и юношей соответственно. Доля доминантного генотипа составила 23,7 и 33,6 \% и рецессивного - 32,3 и 11,2 \% у девушек и юношей соответственно. Удлиненные интервалы QRS, P, ассоциированные с рецессивным генотипом гена SERPINE1 (PAI-1), на 7-10 \% чаще встречаются у юношей. Сниженные значения ЧСС и угла альфа в группе лиц с рецессивным генотипом гена встречаются у девушек в 1,7 и 2,7 раза чаще, чем у юношей. Заключение. Выявлены электрокардиографические показатели, ассоциированные с мутацией гена SERPAIN (PAI-1) у юных спортсменов, имеющие важное прогностическое значение в оценке риска сердечно-сосудистых катастроф. Установлено, что для носителей генотипа SERPINE1 (PAI-1) 4G/4G спортивные нагрузки (занятия профессиональным спортом) возможны под контролем врача-кардиолога.

Ключевые слова: полиморфизм гена SERPAIN (PAI-1), ЭКГ, юные спортсмены.

\section{Лuтература}

1. Дегтярёва, Е.А. Миокардит у юных спортсменов / Е.А. Дегтярёва, М.Г. Кантемирова, О.И. Жданова, О.Н. Трошева // Казанский мед. журнал. - 2015. - Т. 96, № 4. - С. 669-674.

2. Комолятова, В.Н. Желудочковые нарушения ритма сердиа у юных элитных спортсменов / В.Н. Комолятова, Л.М. Макаров, Н.Н. Федина и др. // Педиатрия. Журнал им. Г.Н. Сперанского. 2015. - T. 94, № 2. - C. 105-109.

3. Курникова, М.В. Физическое развитие и заболеваемость высококвалифицированных спортсменов подросткового возраста / М.В. Курникова // Ученые записки СПбГМУ им. И.П. Павлова. - 2008. - Т. 15, № 4. - С. 65-66.

4. Левиикий, С.Н. Роль полиморфизма генов ренин-ангиотензиновой системы в формировании сердечно-сосудистой патологии / С.Н. Левицкий, О.А. Первухина, Н.А. Бебякова // Вестник Северного (Арктического) федерального университета. Серия «Медико-биологические науки». 2016. - № 4. - C. 30-39. DOI: 10.17238/issn2308-3174.2016.4.30

5. Макарова, Г.А. Электрокардиограмма спортсмена: норма, патология и потенциально опасная зона: моногр. / Г.А. Макарова, Т.С. Гуревич, Е.Е. Ачкасов, С.Ю. Юрьев. - М.: СПОРТ, 2018. $-256 c$.

6. Пушкарев, В.П. Исследование влияния генетических вариаџий, ассоџиированных с тромбофилией, на спортивную успешность / В.П. Пушкарев, Д.А. Дятлов, Е.В. Леконщев и др. // Лечебная физкультура и спортивная медицина. - 2011. - № 12. - С. 23-28.

7. Ярышева, В.Б. Генетические предикторы адаптачии сердечно-сосудистой системы подростков к физическим нагрузкам / В.Б. Ярышева, Д.З. Шибкова // Казанский мед. журнал. - 2011. № 12. - C. 23-28. DOI: 10.17750/KMJ2017-63

8. A 10-year review of sudden death during sporting activities / M. Dennis, A. Elder, C. Semsarian et al. // Heart Rhythm. - 2018. - Vol. 15. - Iss. 10. - P. 1477-1483. DOI: 10.1016/j.hrthm.2018.04.019

9. Active PAI-1 as marker for venous thromboembolism: Case-control study using a comprehensive panel of PAI-1 and TAFI assays / L. Bollen, M. Peetermans, M. Peeters et al. // Thrombosis Research. - 2014. - Vol. 134 (5). - P. 1097-1102.

10. Strategies for assessing the prevalence of cardiovascular sudden deaths in young competitive athletes / B.J. Maron, C.J. Murphy, T.S. Haas et al. // International Journal of Cardiology. - 2014. Vol. 173. - Iss. 3. - P. 369-372. DOI: 10.1016/j.ijcard.2014.02.021

11. Sudden death and ventricular arrhythmias in athletes: screening, de-training and the role of catheter ablation / M.D. Flannery, A.L. Gerche // Heart, Lung and Circulation, In press, uncorrected proof, Available online 19 Oct. 2018. DOI: 10.1016/j.hlc.2018.10.004

12. The roles of PAI-1 genepolymorphisms in atherosclerotic diseases: A systematic review and meta-analysis involving 149,908 subjects / Y. Liu, J. Cheng, X. Guo et al. // Gene. - 2018. - Vol. 673. P. 167-173. 
Шибкова Дарья Захаровна, доктор биологических наук, профессор, главный научный сотрудник центра спортивной науки, Южно-Уральский государственный университет. 454080, г. Челябинск, проспект Ленина, 76. E-mail: shibkova2006@mail.ru, ORCID: 0000-0002-8583-6821.

Ярышева Виктория Борисовна, врач-кардиолог, клиника «Венозная эстетическая хирургия». 454004, г. Челябинск, ул. Братьев Кашириных, 165. E-mail: yarysheva@list.ru, ORCID: 0000-0002-6713-6637.

Байгужин Павел Азифович, доктор биологических наук, доцент, ведущий научный сотрудник центра спортивной науки, Южно-Уральский государственный университет. 454080, г. Челябинск, проспект Ленина, 76. E-mail: baiguzhinpa@cspu.ru, ORCID: 0000-0002-5092-0943.

Романов Юрий Николаевич, доктор биологических наук, профессор, профессор кафедры спортивного совершенствования, Южно-Уральский государственный университет. 454080, г. Челябинск, проспект Ленина, 76. E-mail: kickbox@mail.ru, ORCID: 0000-0002-0516-9505.

Поступила в редакцию 12 декабря 2018 г.

\section{ОБРАЗЕЦ ЦИТИРОВАНИЯ}

Electrocardiographic Values Associated with SERPAIN (PAI-1) Gene Mutation Sensitivity in Young Athletes for Forecasting Cardiovascular Disorders / D.Z. Shibkova, V.B. Yarysheva, P.A. Baiguzhin, Yu.N. Romanov // Человек. Спорт. Медицина. - 2018. - Т. 18, № S. - C. 7-12. DOI: 10.14529/hsm18s01

\section{FOR CITATION}

Shibkova D.Z., Yarysheva V.B., Baiguzhin P.A., Romanov Yu.N. Electrocardiographic Values Associated with SERPAIN (PAI-1) Gene Mutation Sensitivity in Young Athletes for Forecasting Cardiovascular Disorders. Human. Sport. Medicine, 2018, vol. 18, no. S, pp. 7-12. DOI: $10.14529 / \mathrm{hsm} 18 \mathrm{~s} 01$ 